are due to the zeal and ability of my colleagues. Thus, Mr. R. L. Jack has the merit of detecting and trac.ng the Caradoc basin of the Leadhills, and of working out the structure of that region which has been of so much service in the subsequent progress of the Survey. Mr. John Horne has carried the lines far into Galloway, and Mr. D. R. Irvine has traced them across a great part of Wigtownshire. Mr. H. Skae has mapped them across Dumfriesshire into Selkirkshire, while Mr. B. N. Peach, besides doing excellent service in the west, is now running them across the rest of the country towards the sea on the east.

Allow me also on the part of my colleagues, as well as for myself, to take advantage of this opportunity to thank Prof. Harkness for his most valuable and welcome papers, and to express our gratification that the labours of the Survey should have found so courteous an exponent, and one whose knowledge of the country which we have mapped is so minute and extensive.

ARCH. GEIKIE

\section{The Huemul}

Is Vol. viit, p. 253 of your valuable journal, I find it noticed that the Chilian Exploring Expedition has taken a specimen of the Huemul, an animal which had altogether been lost sight of, and first described by Molina under the name of Equzhs bisulcus. This notice is not correct, as the animal has been described already in 1846 by Messrs. Gray and Gervais, in the $\mathrm{An}$ nales dtr scient. natur. iii. Ser. Tom. v. page $9 \mathbf{I}$, under the name of Cerzus chilensis, and compared with C. antisiensis of D'Orbigny, as the species most nearly allied to the Huemul or Guemul or Guamel, different names for the same animal in different parts of the country. This first description was repeated the following year in the "Historia fisica y Politica de Chile," Zoology, vol. i. page 159 , and accompanied by the figure of the animal (pl. Io, and its skull pl. 11), from the only known specimen of a young male of half-grown size, brought to Paris by Mr. Gay. On the same specimen Mr. Pucheran has founded his description in his valuable monograph of the genus Ctrvus, published in the Archives du Museum, vol. vi. page 965 (1862), and from these two descriptions Mr. A. Warner has given a combined extract in his "Saugethiere," \&c. Tom. v. (supplement), page 382 , under the same name of Ceruis chilensis. Meanwhile Dr. J. E. Gray had described a species of deer, received by the Earl of Derby from Chili as Cervus leucotis (Annals of Nat. Hist. ii., Jer. Tom. v. page 324 , 1840 , and Proceed. Zool. Soc., I849, page 64, pl. I2), which name he soon changed to Furcifer Huamel (Annals chr. iv. 427), and at last to Xenelaphus huamel, adding to his first description new notices, with the figures of the horns of the male (Proceed. Zool. Soc., 1869, page 496), and the skull of the female, and stating that his Cervus leucotis is identical with the Cervus chilensis of Gay. This exposition proves that the Huemul or Guemul is already a very well-known animal, and has by no means been overlook ed by naturalists.

A young collector in Buenos Ayres, Mr. Franc Moreno, has lately received a pair of these animals from Patagonia, where they were caught by the Indian Pehnelches, who live on the western foot of the Cordilleras, near the sources of the rivers Negro and Colorado. These two specimens have been brought to the public Museum, where I have examined them carefully. The male is a young one, with horns still covered by the skin, and only 3 in. long, without branches. I regret that therefore I can say nothing about the figure of the adult's horns, which are according to the drawing given by my dear friend, Dr. Gray, very like that of the roebuck, although the specimen he has figured may be regarded as in an abnormal state, from the great difference between their two sides. Both sexes of the animal are of equal size- $3 \mathrm{ft}$. high on back, and $4 \frac{1}{2} \mathrm{ft}$. long, the head being ro in. long, the ears and the neck 7 in. every one, and the body $3 \mathrm{ft}$. without the tail, which measures 7 in. with its hairs, but only $4 \mathrm{in}$. in the axis. Great naked lachrymal pits are seen below the eyes. The fur is of the same quality in each, but very different in the cold and in the warm seasons; then both skins are in the time of hairing, the female with the prevailing bair of the winter, and the male with the prevailing of the summer. Each hair is not entirely straight, but some are undulated, principally on the under half, and this undulated portion has a clear greyish-brown colour; over this clearer portion comes a broad dark-brown or black ring, and the end is clear reddish yellow, with a fine blackish tip, generally broken off in old fur. For the winter dress the hairs are 2 in. to $2 \frac{1}{2}$ in. long, and of a less characteristic colour, being over the whole skin of an undistinguished greyish-brown colour; but in the summer dress the hairs measure no more than $1 \frac{1}{4}$ in. or $\mathrm{I} \frac{1}{9}$ in., and all their colours are cleaner and better pronounced. Therefore the animal is darker and more distinguished in colour in the summer than in the winter. The hairs on the face are very short, as are those on the outside of the ears, somewhat longer on thelegs, but nearly as short on the under half part of the extremities. The breast and the tail have the longest hairs. Different in colour are the naked nose and upper lip, both entirely black ; the breast is dark blackish-brown, the genital region to the tail, with the inside of the hinder upper legs being white. The same colour also pervades the inside of the ears, which are coated with long hairs; the hoofs. are black. No tinge of the particular stripe of longer hairs on the tarsus of the hinder legs is conspicuous in either sex; but I find, with Dr. Gray, a large tuft of longer hairs on the hock, on the inside behind, which makes this part of the legs very thick.

The animal lives principally in the valleys of the Cordilleras, but on both sides, the eastern and the western, and rarely goes down to the flat country of the Argentine pampas. Its proper range is between $35^{\circ}$ and $45^{\circ}$. It is well known by the Indians, who not only make use of its strong skin for wardress, and its meat for food, but also tame young animals, using them for domestic employment, like the Guanaco, which lives in the same territory, but is much more common, and therefore almost the only animal used for hunting by the same people.

Buenos Ayres, Sept. 20

Dr. Burmeister

The Diverticulum of the Small Intestine considered as a Rudimentary Structure

I MUST claim the opportunity of reply to the article which appeared in your number of October I6 (vol. viii p. 509), entitled "On the Appendix Vermiformis and the Evolution Hypothesis," which the writer offers as a commentary on my little paper at the recent meeting of the British Association, "On the Diverticulum of the Small Intestine considered as a Rudimentary Structure."

The writer seems to have been misled by newspaper reports. None of these were furnished by me, or submitted to me before publication, and in those which I saw after their publication both the anatomy and the argument were grossly and indeed absurdly blundered. This applies not only to my paper and remarks, but to the remarks made by those who spoke on my paper. It was, perhaps, too much to expect newspaper reporters not to get confused among scientific terms, and I may have erred in not having the usual abstract of my little paper ready to hand to the reporters.

Newspaper reports may be passed without notice, but I cannot allow an article in a scientific periodical to pass in which the writer uses such language as the following, with which the article in your columns concludes :-

"To quote the words of one of the greatest of our physiclo. gists, it can only bring ignominy on the body of scientific workers if they are supposed to countenance such an argument as that of Prof. Struthers, which assumes that because one or two indivi. duals have died from the impactation of cherry-stones in the appendix vermiformis, therefore there is no God!"

The "no God" was certainly not in my paper or in anything I have ever written or spoken, and the accusation is to me so offensive that I repudiate it with indignation. How anyone should suppose that the evolution hypothesis implies that there is "no God" I am at a loss to understand. I supposed it to be well understood that, on the contrary, that great hypothesis enables us to rise to higher conceptions, the only question being the mode of proceeding.

As to the scientific argument, it seems hopeless to at empt to unravel the confusion into which newspaper reports and my critic have brought it, except by re-stating my argument. But this is for the most part unnecessary after your publication of my abstract in the number following that in which the article of which I complain appeared. It cannot be absolutely proved that the appendix vermiformis is useless, though a survey of the facts in comparative anatomy and development leads to the inference that it is a rudimentary structure. But my paper was on the diverticulum, the appendix being referred to only collaterally, and more for the sake of clearing away the most unnece sary teleology with which it has been encrusted, than with the view of resting the argument on it. The diverticulum, like the appendix, has glands and mus. cular layers, secreting and expelling ; it has villi; actively absorbing; and it is large, which the appendix is not. Yet, notwith standing all this elaborate construction and this activity, who will maintain that this unclosed bit of the vitelline duct has been left 